\title{
Desulfitibacter alkalitolerans gen. nov., sp. nov., an anaerobic, alkalitolerant, sulfite-reducing bacterium isolated from a district heating plant
}

\author{
Marie Bank Nielsen, Kasper Urup Kjeldsen and Kjeld Ingvorsen \\ Department of Microbiology, University of Aarhus, Ny Munkegade Building 1540, DK-8000 \\ Aarhus C, Denmark
}

Correspondence

Kjeld Ingvorsen

kjeld.ingvorsen@biology.au.dk

\begin{abstract}
A novel alkalitolerant, anaerobic bacterium, designated strain sk.kt5 ${ }^{\top}$, was isolated from a metal coupon retrieved from a corrosion-monitoring reactor of a Danish district heating plant (Skanderborg, Jutland). The cells of strain sk.kt5 ${ }^{\top}$ were motile, rod-shaped $(0.4-0.6 \times$ 2.5-9.6 $\mu \mathrm{m})$, stained Gram-positive and formed endospores. Strain sk.kt5 ${ }^{\top}$ grew at $\mathrm{pH} 7 \cdot 6-10 \cdot 5$ (with optimum growth at $\mathrm{pH} 8 \cdot 0-9 \cdot 5$ ), at temperatures in the range $23-44^{\circ} \mathrm{C}$ (with optimum growth at $35-37^{\circ} \mathrm{C}$ ), at $\mathrm{NaCl}$ concentrations in the range $0-5 \%(w / v)$ (with optimum growth at $0-0.5 \%)$ and required yeast extract for growth. Only a limited number of substrates were utilized as electron donors, including betaine, formate, lactate, methanol, choline and pyruvate. Elemental sulfur, sulfite, thiosulfate, nitrate and nitrite, but not sulfate or Fe(III) citrate, were used as electron acceptors. The $\mathrm{G}+\mathrm{C}$ content of the DNA was $41.6 \mathrm{~mol} \%$. Phylogenetic analyses of the sequence data for the $d s r A B$ genes [encoding the major subunits of dissimilatory (bi)sulfite reductase] and the $16 \mathrm{~S}$ rRNA gene placed strain sk.kt5 ${ }^{\top}$ within a novel lineage in the class Clostridia of the phylum Firmicutes. Taken together, the physiological and genotypic data suggest that strain sk.kt5 ${ }^{\top}$ represents a novel species within a novel genus, for which the name Desulfitibacter alkalitolerans gen. nov., sp. nov. is proposed. The type strain of Desulfitibacter alkalitolerans is sk.kt5 ${ }^{\top}\left(=\mathrm{JCM} 12761^{\top}=\mathrm{DSM} 16504^{\top}\right)$.
\end{abstract}

The pipe networks of district heating systems constitute a unique aqueous environment, characterized by anoxia, low nutrient availability, high $\mathrm{pH}(9 \cdot 5-10 \cdot 0)$ and relatively high temperatures $\left(\geqslant 40{ }^{\circ} \mathrm{C}\right)$. These extreme conditions serve to minimize chemical corrosion and limit bacterial growth. However, oligotrophic conditions may not be sufficient to prevent biofilm formation in a flow system, since nutrients are constantly being replenished and tend to concentrate on submerged surfaces, thus promoting attached bacterial growth. Such biofilm formation can locally alter the surface chemistry, which in turn can result in (bio)corrosion of the surface (Hamilton, 1995; Little et al., 1990). Sulfatereducing bacteria are generally considered as the major causative agent of biocorrosion because of their ability to produce corrosive hydrogen sulfide and/or to consume molecular hydrogen (Lee et al., 1995; Hamilton, 1995). Biocorrosion is of particular importance in high-sulfate marine technical systems, especially those in the offshore oil industry, and can cause substantial economic losses (Marshall, 1992). However, biocorrosion can also occur in low-sulfate freshwater systems such as district heating

The GenBank/EMBL/DDBJ accession numbers for the dsrAB and 16S rRNA gene sequences of strain sk.kt5 $5^{\top}$ are $A Y 538171$ and AY751285, respectively. networks, as was highlighted by recent surveys showing that several Danish district heating systems occasionally suffer from biocorrosion (Kjellerup et al., 2003, 2005). Attempts by those authors to link the occurrence of biocorrosion specifically to the presence of sulfate-reducing bacteria proved unsuccessful, suggesting that other types of microorganisms might also be involved in biocorrosion processes.

Here, we describe a novel alkalitolerant, sulfide-producing, anaerobic bacterium, strain sk.kt $5^{\mathrm{T}}$, isolated from a biofilm sample from a Danish district heating system that had previously suffered from failures due to biocorrosion.

Strain sk.kt $5^{\mathrm{T}}$ was enriched from biofilms that developed on mild steel coupons during a 4 month incubation period in a corrosion-monitoring reactor connected to the return line (bulk water $\mathrm{pH} 9 \cdot 5-10 \cdot 0,40{ }^{\circ} \mathrm{C}$ ) of Skanderborg District Heating Plant in Denmark. The water-quality parameters of this system have been reported previously (Abildgaard et al., 2006). Enrichment cultures were initiated by inoculating biofilm material aseptically scraped off metal coupons and suspended in approximately $1 \mathrm{ml}$ filter-sterilized $(0 \cdot 2 \mu \mathrm{m}$ pore size) district heating water into a modified version of Postgate's medium B (Postgate, 1984) containing the following ( ${ }^{-1}$ MilliQ water): $0.5 \mathrm{~g} \mathrm{KH}_{2} \mathrm{PO}_{4}, 0.25 \mathrm{~g} \mathrm{NH}_{4} \mathrm{Cl}$, $1.26 \mathrm{~g} \mathrm{CaSO}_{4} .2 \mathrm{H}_{2} \mathrm{O}, \quad 1.0 \mathrm{~g} \quad \mathrm{MgSO}_{4} .7 \mathrm{H}_{2} \mathrm{O}, \quad 0.1 \mathrm{~g}$ 
$\mathrm{FeSO}_{4} .7 \mathrm{H}_{2} \mathrm{O}, 0.2 \mathrm{~g}$ yeast extract, $1.0 \mathrm{ml}$ trace element mixture (Widdel \& Bak, 1992), $1.0 \mathrm{ml}$ selenite/tungstate mixture (Widdel \& Bak, 1992) and $50 \mu$ resazurin solution $(2 \%, w / v)$. After sterilization of the medium, the following solutions were added aseptically from sterile anoxic stocks $\left(1^{-1}\right.$ medium): $1.0 \mathrm{ml}$ vitamin mixture [modified after Widdel \& Bak (1992) by including $30 \mathrm{mg}$ folic acid $\mathrm{l}^{-1}$, $1.0 \mathrm{ml}$ vitamin $\mathrm{B}_{12}$ solution and $1.0 \mathrm{ml}$ thiamine solution (Widdel \& Bak, 1992). The following substrates were each added to a final concentration of $5 \mathrm{mM}$ : propionate, acetate, lactate and ethanol. Before use, the $\mathrm{pH}$ of the medium was adjusted to $9 \cdot 0$ using sterile, anoxic $\mathrm{NaOH}(4 \mathrm{M})$ and the medium was finally reduced by adding a $2 \%(\mathrm{w} / \mathrm{v})$ sodium dithionite solution $\left(3 \mathrm{ml} \mathrm{l}^{-1}\right)$. Enrichment cultures were incubated at $40^{\circ} \mathrm{C}$ in the dark. Strain sk.kt5 $5^{\mathrm{T}}$ was isolated from one of the enrichment cultures by repeated $(3 \times)$ application of the roll-tube technique (Hungate, 1976), using the same medium as described above but further supplemented with $10 \mathrm{mM}$ thiosulfate and washed agar $(2 \%, \mathrm{w} / \mathrm{v})$. The purity of the isolated culture was examined by phase-contrast microscopy after growth $($ at $\mathrm{pH} 7 \cdot 0,8 \cdot 0$ and $9 \cdot 0$ ) in the above-mentioned medium supplemented with $20 \mathrm{mM}$ glucose, $20 \mathrm{mM}$ lactate and $10 \mathrm{mM}$ thiosulfate.

Routine cultivation and all growth tests were performed in $16 \times 125 \mathrm{~mm}$ Hungate anaerobic culture tubes (Bellco Glass) containing $10 \mathrm{ml}$ basal medium buffered with CAPSO (3-cyclohexylamino-2-hydroxy-1-propanesulfonic acid, $\mathrm{p} K_{\mathrm{a}} 9 \cdot 6$ ) prepared as described previously (Abildgaard et al., 2006). Unless noted otherwise, the $\mathrm{pH}$ of the basal medium was adjusted to $9 \cdot 0$ (measured at $40{ }^{\circ} \mathrm{C}$ ), the medium was supplemented with betaine and thiosulfate (20 $\mathrm{mM}$ each) and all incubations were carried out in duplicate at $40{ }^{\circ} \mathrm{C}$ in the dark. Cell growth was quantified by measuring optical density at $600 \mathrm{~nm}\left(\mathrm{OD}_{600}\right)$. Because of the formation of inorganic precipitates in the basal medium at $\mathrm{pH}$ values greater than $9 \cdot 0, \mathrm{OD}_{600}$ measurements were sometimes supplemented with measurements of sulfide production (performed using the method of Cline, 1969) and with total counts of SYBR Gold-stained cells (performed according to Mogensen et al., 2005). Transmission electron microscopy was performed as described previously (Mogensen et al., 2005). The Gram-staining reaction was determined by using a standard procedure. The $\mathrm{pH}$ range for growth was determined at 11 different $\mathrm{pH}$ values ranging from $6 \cdot 3$ to $10 \cdot 5$, obtained by titrating the medium with sterile, anoxic $2 \mathrm{M} \mathrm{HCl}$ or $\mathrm{NaOH}$ solutions. The $\mathrm{pH}$ did not remain stable when titrated to values above $10 \cdot 5$, so growth of the strain was not evaluated at higher $\mathrm{pH}$. The temperature range for growth was determined using a temperature-gradient block (Elsgaard et al., 1994) at 21 different temperatures ranging from 0.6 to $50 \cdot 2{ }^{\circ} \mathrm{C}$. The effect of $\mathrm{NaCl}$ on growth was determined at $0 \cdot 1,0 \cdot 5,1 \cdot 0$, $2 \cdot 5,5 \cdot 0,5 \cdot 5,6 \cdot 0,6 \cdot 5,7 \cdot 0,7 \cdot 5,10,15$ and $20 \%(\mathrm{w} / \mathrm{v})$. The ability of strain sk.kt $5^{\mathrm{T}}$ to utilize different electron donors was tested in separate incubations using both thiosulfate $(20 \mathrm{mM})$ and sulfite $(10 \mathrm{mM})$ as electron acceptors. The fermentative abilities of strain sk.kt $5^{\mathrm{T}}$ were tested in medium devoid of external electron acceptors. The utilization of different electron acceptors was tested using betaine $(20 \mathrm{mM})$ and yeast extract $\left(0.5 \mathrm{~g} \mathrm{l}^{-1}\right)$ as electron donors. Cultures grown in medium with $20 \mathrm{mM}$ betaine and $0.5 \mathrm{~g} \mathrm{l}^{-1}$ yeast extract without any external electron acceptors were used as inocula $(5 \%, v / v)$ for the latter experiments. The reduction of $\mathrm{Fe}(\mathrm{III})$ citrate $(20 \mathrm{mM})$ was examined in unreduced medium by measuring the $\mathrm{Fe}$ (II) concentration by means of the ferrozine method (Lovley \& Phillips, 1986). Notably, strain sk.kt $5^{\mathrm{T}}$ was capable of initiating growth in unreduced medium when the inoculum was from betaine-grown cultures. The reduction of nitrate $(20 \mathrm{mM})$ and nitrite $(2 \mathrm{mM})$ was tested (five replicate cultures each) by measuring the $\mathrm{OD}_{600}$ and by monitoring the concentrations of nitrate and nitrite using HPLC (Kjeldsen et al., 2004), as well as by assessing the ammonium concentration by using a colorimetric method (Bower \& Holm-Hansen, 1980). Plating on agar plates $(1.5 \%$, w/v) consisting of basal medium ( $\mathrm{pH} \mathrm{9 \cdot 0)}$ was used to test for aerobic growth.

The cells of strain sk.kt5 ${ }^{\mathrm{T}}$ were motile straight rods varying in size from 0.4 to $0.6 \mu \mathrm{m}$ in diameter and from 2.5 to $9 \cdot 6 \mu \mathrm{m}$ in length (Fig. 1). Strain sk.kt5 ${ }^{\mathrm{T}}$ stained Grampositive and formed round terminal endospores (Fig. 1). The temperature range for growth was $23-44^{\circ} \mathrm{C}$, with an optimum at $35-37^{\circ} \mathrm{C}$. After 120 days incubation, growth was detected at temperatures down to $14 \cdot 5^{\circ} \mathrm{C}$. No growth

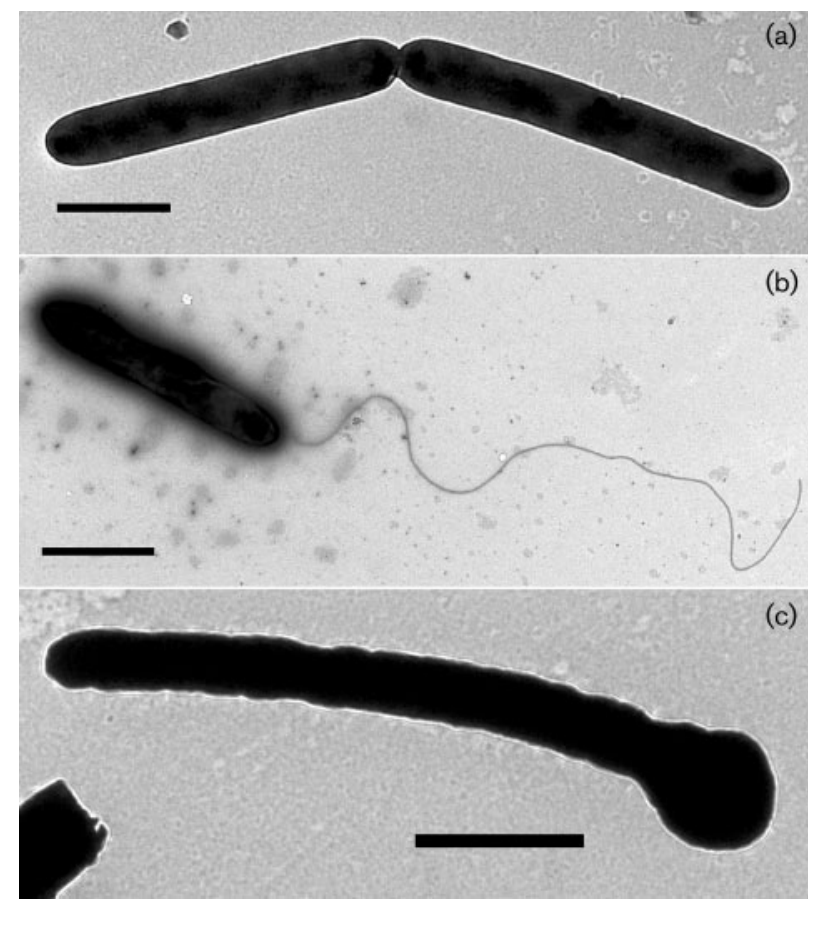

Fig. 1. Transmission electron micrographs of uranyl acetatestained cells of strain sk.kt5 ${ }^{\top}$. (a) Dividing cells. (b) Cell with polar flagellum. (c) Cell with terminal endospore. Bars, $1.0 \mu \mathrm{m}$ (a, c) and $2.0 \mu \mathrm{m}(\mathrm{b})$. 
was detected at $48{ }^{\circ} \mathrm{C}$ or at $\leqslant 11^{\circ} \mathrm{C}$. Cultures of strain sk.kt $5^{\mathrm{T}}$ survived pasteurization for $4 \mathrm{~h}$ at $60^{\circ} \mathrm{C}$. The $\mathrm{pH}$ range for growth was $\mathrm{pH} 7.6$ to approximately $\mathrm{pH} 10.5$ (strain sk.kt $5^{\mathrm{T}}$ exhibited only weak growth at this $\mathrm{pH}$; higher values were not tested, as mentioned above); optimum growth occurred at $\mathrm{pH} 8 \cdot 0-9 \cdot 5$. Growth was not observed at or below $\mathrm{pH} 7 \cdot 5$. Strain sk.kt $5^{\mathrm{T}}$ grew at $\mathrm{NaCl}$ concentrations ranging from 0 to $5 \%(\mathrm{w} / \mathrm{v})$, the optimum being observed at $0-0 \cdot 5 \%(\mathrm{w} / \mathrm{v}) \mathrm{NaCl}$.

Yeast extract was required for growth and could not be replaced by a vitamin mixture. Strain sk.kt $5^{\mathrm{T}}$ grew on yeast extract $\left(0 \cdot 5 \mathrm{~g} \mathrm{l}^{-1}\right)$ as the sole substrate, both fermentatively and with thiosulfate or sulfite present as the electron acceptor. Under the latter conditions, the observed increases in $\mathrm{OD}_{600}$ values during incubation ranged from $0 \cdot 05$ to $0 \cdot 07$. Therefore, in growth tests, only those compounds yielding $\mathrm{OD}_{600}$ increments of at least 0.09 were scored as growth substrates. In the presence of thiosulfate $(20 \mathrm{mM})$, strain sk.kt ${ }^{\mathrm{T}}$ grew on betaine $(30 \mathrm{mM})$, formate $(50 \mathrm{mM})$, lactate $(30 \mathrm{mM})$, methanol $(50 \mathrm{mM})$ and pyruvate $(40 \mathrm{mM})$, with $\mathrm{OD}_{600}$ values ranging from 0.09 to $0 \cdot 17$. The sulfide concentrations produced with these electron donors varied between 2.0 and $6.8 \mathrm{mM}$. In the presence of sulfite $(10 \mathrm{mM})$, the strain also grew on choline $(30 \mathrm{mM})$ (but not on formate at $50 \mathrm{mM}$ ), with $\mathrm{OD}_{600}$ values ranging from $0 \cdot 12$ to $0 \cdot 23$, and produced sulfide concentrations varying between 5.0 and $10.0 \mathrm{mM}$. In the presence of thiosulfate or sulfite, the strain did not grow on $\mathrm{H}_{2} / \mathrm{CO}_{2}$, acetate $(20 \mathrm{mM})$, acetone $(20 \mathrm{mM}), \mathrm{D}(-)$-arabinose $(20 \mathrm{mM})$, benzoate $(30 \mathrm{mM})$, 2-butanol $(40 \mathrm{mM})$, butyrate $(40 \mathrm{mM})$, Casamino acids $(30 \mathrm{mM})$, choline $(30 \mathrm{mM})$, ethanol $(50 \mathrm{mM}), \mathrm{D}(-)$-fructose $(30 \mathrm{mM})$, fumarate $(20 \mathrm{mM})$, $\mathrm{D}(+)$-galactose $(20 \mathrm{mM}), \mathrm{D}(+)$-glucose $(20 \mathrm{mM})$, glycerol $(30 \mathrm{mM})$, glycine $(40 \mathrm{mM})$, DL-malate $(30 \mathrm{mM}), \mathrm{D}(+)$ mannose $(30 \mathrm{mM})$, 1-pentanol $(30 \mathrm{mM})$, 2-propanol $(50 \mathrm{mM})$, propionate $(40 \mathrm{mM}), \mathrm{L}(+)$-rhamnose $(30 \mathrm{mM})$, succinate $(40 \mathrm{mM})$, sucrose $(20 \mathrm{mM})$ or $\mathrm{D}(+)$-xylose $(30 \mathrm{mM})$. Besides fermenting yeast extract, strain sk.kt5 ${ }^{\mathrm{T}}$ was able to grow fermentatively (at low growth rates) on betaine $(20 \mathrm{mM})$. With betaine as the electron donor, strain sk.kt $5^{\mathrm{T}}$ reduced elemental sulfur, sulfite and thiosulfate to sulfide. Both nitrate and nitrite were reduced, but nitrite inhibited growth at concentrations of $2 \mathrm{mM}$ or more. Apparently neither $\mathrm{N}_{2}$ (as evident from the absence of gas production) nor ammonium was an end-product of nitrate or of nitrite reduction. Strain sk.kt $5^{\mathrm{T}}$ did not reduce sulfate or $\mathrm{Fe}(\mathrm{III})$ citrate. The strain did not grow under oxic conditions.

Genomic DNA of strain sk.kt $5^{\mathrm{T}}$ was extracted and the $d s r A B$ [encoding the alpha and beta subunits of dissimilatory (bi)sulfite reductase] and 16S rRNA gene sequences were retrieved as described previously (Abildgaard et al., 2006). A custom-designed internal $d s r A B$ sequencing primer (5'-GATGCATGCACTGTATTAACAAA-3', annealing to Desulfovibrio vulgaris $d s r A$ positions 728-751) was used to complete the $d s r A B$ sequence of strain sk.kt $5^{\mathrm{T}}$. The $16 \mathrm{~S}$ rRNA gene sequence of strain sk.kt $5^{\mathrm{T}}$ was aligned according to the ssu_jan04_corr_opt.arb ARB database (available at http://www.arb-home.de). Phylogenetic trees (based on datasets of sequences $>1350 \mathrm{nt}$ ) were constructed using the neighbour-joining (with Jukes-Cantor distance correction), maximum-parsimony and maximum-likelihood algorithms of the ARB package (Ludwig et al., 2004). A $50 \%$ conservation filter calculated for the taxa shown in Fig. 2(a) was applied to select sequence positions (1277 nt) for the analyses. The phylogenetic analysis of the $d s r A B$ sequence of strain sk.kt $5^{\mathrm{T}}$ was carried out as described previously (Abildgaard et al., 2006) and included 457 unambiguously aligned amino acid sequence positions. Bootstrap analyses were performed and phylogenetic consensus trees were constructed as described previously (Abildgaard et al., 2006).

Initial phylogenetic analysis of the $16 \mathrm{~S}$ rRNA gene sequence of strain sk.kt $5^{\mathrm{T}}$, performed using BLAST searches, revealed that the novel strain has no close relatives among recognized bacterial species, the highest level of similarity $(89 \%)$ being shared with members of the Gram-positive genus Moorella (Moorella thermoacetica DSM $521^{\mathrm{T}}$ and Moorella thermoautotrophica DSM $1974^{\mathrm{T}}$ ). However, $>97 \%$ similarity was shared with a number of environmentally derived $16 \mathrm{~S}$ rRNA gene sequence clones representing uncultivated bacteria originating from alkaline water samples from a South African gold mine (Baker et al., 2003; GenBank accession numbers AF486695, AY540791, AY540795, AY540811, AY540821 and AY540824). Phylogenetic treeing consistently placed strain sk.kt5 ${ }^{\mathrm{T}}$ within the class Clostridia of the phylum Firmicutes as a novel sister lineage to the genus Moorella (Fig. 2a). Calculation of pairwise similarities from full-length alignment of all taxa included in the tree shown in Fig. 2(a), using the Firmicutes filter of the ssu_jan04_ corr_opt.arb ARB database or a filter based on the Lane mask (which excludes all hypervariable sequence positions of the 16S rRNA gene; Lane, 1991), identified the two abovementioned Moorella species and Moorella glycerini DSM $11254^{\mathrm{T}}$ as the closest relatives of strain sk.kt $5^{\mathrm{T}}(91 \cdot 5-91 \cdot 8 \%$ similarity). Similarity values that were $0 \cdot 5-1 \cdot 5 \%$ lower were shared with several species belonging to different genera, including certain members of the sulfate-reducing genus Desulfotomaculum. Even lower levels of similarity $(89 \cdot 1-89 \cdot 2 \%)$ were shared with Moorella mulderi DSM $14980^{\mathrm{T}}$, which, together with the three above-mentioned species, constitute the only members of the genus Moorella that have validly published names. Like strain sk.kt $5^{\mathrm{T}}$, the latter species are all anaerobic, Gram-positive, sporeforming rods capable of using thiosulfate as an electron acceptor (Fontaine et al., 1942; Wiegel et al., 1981; Ljungdahl, 1986; Slobodkin et al., 1997; Balk et al., 2003). However, apart from the above-mentioned similarities, a number of phenotypic and genotypic properties differentiate strain sk.kt $5^{\mathrm{T}}$ from this genus. Most notably, the genomic $\mathrm{G}+\mathrm{C}$ content of strain sk.kt5 ${ }^{\mathrm{T}}(41.6 \mathrm{~mol} \%$; determined by HPLC analysis at the Identification Service of Deutsche Sammlung von Mikroorganismen und Zellkulturen, Braunschweig, Germany) differs by more 
(a)

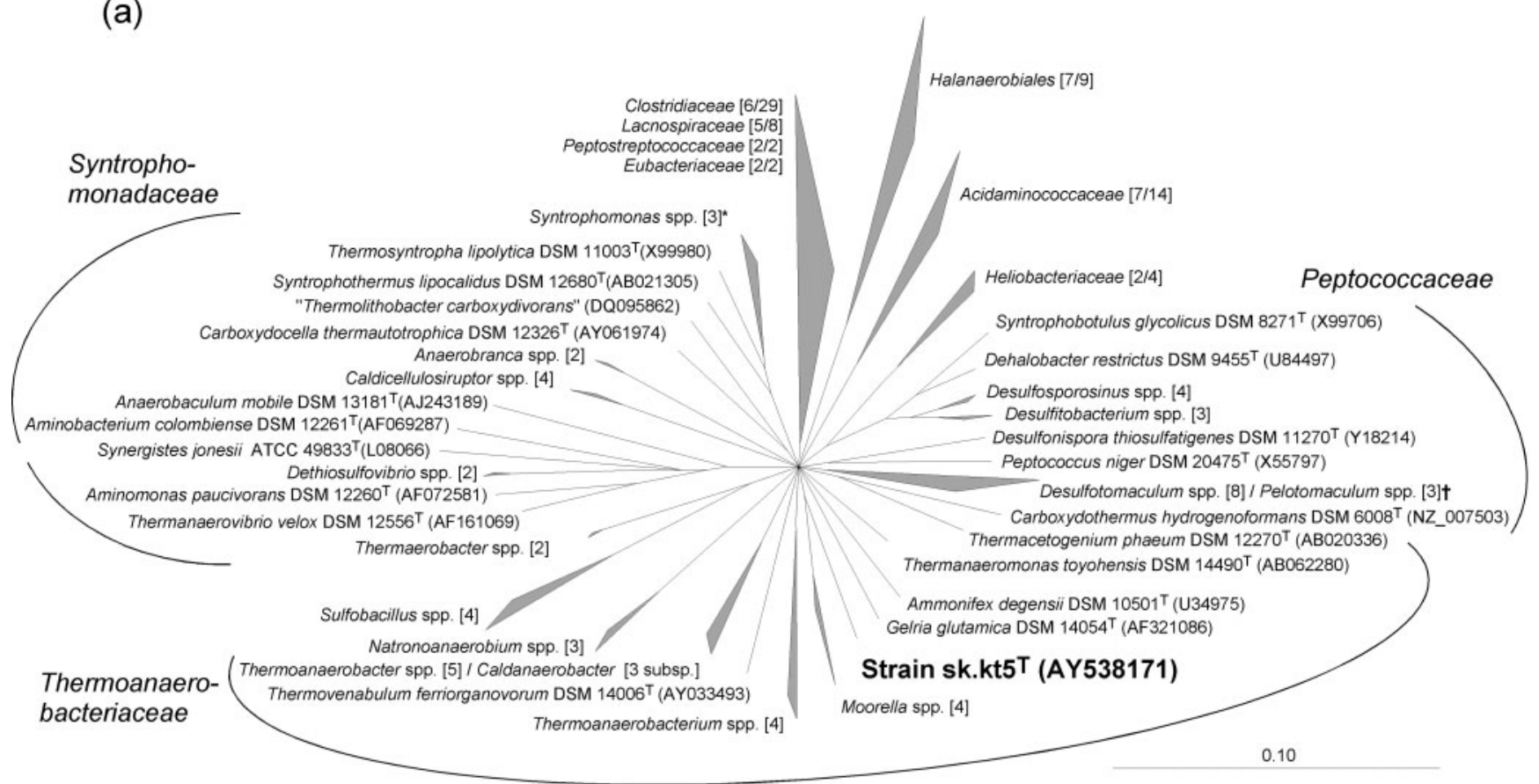

(b)

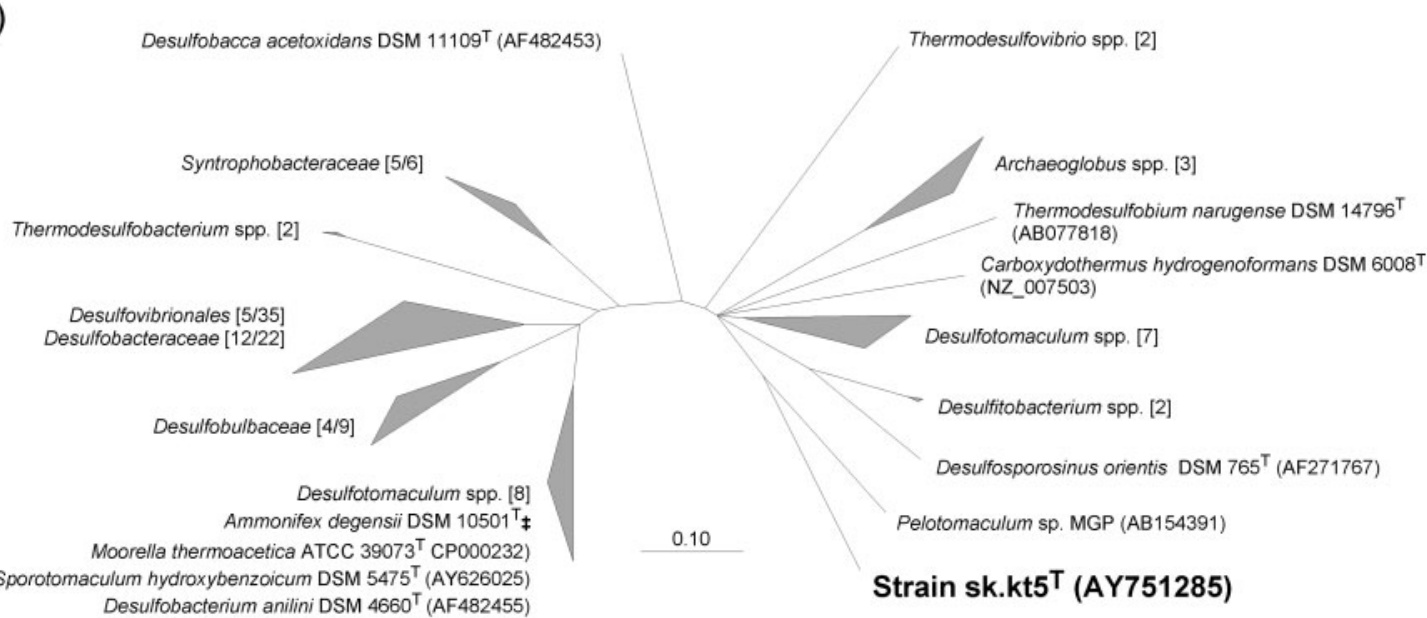

Fig. 2. Unrooted consensus trees showing the phylogenetic affiliation of the $16 S$ rRNA gene (a) and DsrAB amino acid (b) sequences of strain sk.kt5 ${ }^{\top}$. Most of the taxa shown in the 16S rRNA gene sequence-based tree are members of the class Clostridia. Multifurcations connect branches that were not resolved unambiguously by distance-matrix, maximum-parsimony and maximum-likelihood treeing methods. Numerals in square brackets indicate the numbers of genera and/or named species constituting the respective grouping. A number of outgroup sequences used to root the tree were subsequently removed. The node connecting the Moorella species and strain sk.kt5 ${ }^{\top}$ lineages in the $16 \mathrm{~S}$ rRNA gene sequence-based tree received 74 and $61 \%$ distance-matrix-based and maximum-parsimony-based bootstrap support, respectively. In the DsrAB-based tree, the node connecting the Pelotomaculum sp. MGP and strain sk.kt5 ${ }^{\top}$ lineages received 90 and $73 \%$ distance-matrix-based and maximum-parsimony-based bootstrap support, respectively. Symbols: *, also including Pelospora glutarica DSM $6652^{\top}$ (GenBank accession no. AJ251214) and Syntrophospora bryantii DSM 3014A ${ }^{\top}$ (M26491); $\dagger$, also including Sporotomaculum hydroxybenzoicum DSM 5475 ${ }^{\top}$ (Y14845); $\ddagger$, a partial dsrAB sequence of Ammonifex degensii DSM $10501^{\top}$ was obtained through the NCBI homepage (http://www.ncbi.nlm.nih.gov) from the trace archive of whole genome shotgun reads from this organism (TI number 662586343). Bars, 10\% sequence divergence inferred from distance-matrix analyses.

than $12 \mathrm{~mol} \%$ from the $\mathrm{G}+\mathrm{C}$ contents of the four Moorella species, which suggests that strain sk.kt $5^{\mathrm{T}}$ should be placed outside this genus (Vandamme et al., 1996). The genus
Moorella belongs to the family Thermoanaerobiaceae; however, as can be seen from the consensus tree shown in Fig. 2(a), the phylogenetic analyses used failed to resolve 
the phylogenetic relationships among the families of the class Clostridia. Thus, strain sk.kt5 ${ }^{\mathrm{T}}$ cannot be confidently assigned to a family.

According to phylogenetic analyses based on DsrAB amino acid sequences, strain sk.kt5 $5^{\mathrm{T}}$ constitutes a novel lineage related to that of the syntrophic Gram-positive bacterium Pelotomaculum sp. MGP (Fig. 2b), which, like strain sk.k $\mathrm{t}^{\mathrm{T}}$, is unable to reduce sulfate (Imachi et al., 2006). Unfortunately, $d s r A B$ sequence information is available only for a single Moorella species, namely $M$. thermoacetica. As can be seen from Fig. 2(b), this sequence clusters together with the xenologous $d s r A B$ sequences of certain members of the class Clostridia, which probably acquired their $d s r A B$ sequences by lateral gene transfer from a deltaproteobacterial donor related to Desulfobacterium anilini DSM $4660^{\mathrm{T}}$ (Zverlov et al., 2005). In contrast, strain sk.kt $5^{\mathrm{T}}$ probably carries an orthologous $d s r A B$ gene, as shown by the congruence between its $d s r A B$ and $16 \mathrm{~S}$ rRNA gene sequence-derived phylogenies (Fig. 2a, b).

The genotypic and phenotypic analyses clearly differentiate sk.kt $5^{\mathrm{T}}$ from its $16 \mathrm{~S}$ rRNA gene sequence-based phylogenetically closest relatives. Thus, we propose that strain sk.kt $5^{\mathrm{T}}$ should be considered as representing a novel species within a novel genus, for which the name Desulfitibacter alkalitolerans gen. nov., sp. nov. is proposed. Desulfitibacter alkalitolerans was isolated from biofilms grown on mild steel coupons in a reactor connected to a district heating plant exhibiting problems with biofilm formation and corrosion. Strain sk.kt $5^{\mathrm{T}}$ is capable of sulfide production through the reduction of elemental sulfur, thiosulfate or sulfite. The latter compounds could be formed transiently in the district heating system as a result of the chemical oxidation of biologically produced sulfide when oxygen is temporary introduced during maintenance/repair of the pipe system. As described in a separate publication (Abildgaard et al., 2006), a novel sulfate-reducing bacterium, Desulfovibrio alkalitolerans DSM $16529^{\mathrm{T}}$, was recently isolated from a biofilm sample of the same district heating plant.

\section{Description of the genus Desulfitibacter gen. nov.}

Desulfitibacter (De.sul.fi.ti.bac'ter. L. pref. de from, off, away; N.L. n. sulfis -itis sulfite; N.L. masc. n. bacter a rod; N.L. masc. n. Desulfitibacter rod-shaped bacterium that reduces sulfite).

Motile, Gram-positive rods. Form terminal endospores. Anaerobic, growing chemoheterotrophically by fermentation or by reduction of sulfite or thiosulfate. The type species is Desulfitibacter alkalitolerans.

\section{Description of Desulfitibacter alkalitolerans sp. nov.}

Desulfitibacter alkalitolerans (N.L. n. alkali alkali; L. pres. part. tolerans tolerating; N.L. part. adj. alkalitolerans alkalitolerating).
Displays the following properties in addition to those given in the genus description. Cells are $0 \cdot 4-0 \cdot 6 \times 2 \cdot 5-9 \cdot 6 \mu \mathrm{m}$ in size, alkalitolerant and mesophilic. The temperature range for growth is $23-44{ }^{\circ} \mathrm{C}$, with an optimum at $35-37^{\circ} \mathrm{C}$. Extended incubation (130 days) facilitates growth at temperatures down to $14 \cdot 5^{\circ} \mathrm{C}$. The $\mathrm{pH}$ range for growth at $40{ }^{\circ} \mathrm{C}$ is $7 \cdot 6-10 \cdot 5$, with an optimum at $\mathrm{pH} 8 \cdot 0-9 \cdot 5$. $\mathrm{NaCl}$ concentrations up to $5 \%(\mathrm{w} / \mathrm{v})$ are tolerated, but the optimal concentration for growth is $0-0.5 \%(\mathrm{w} / \mathrm{v})$. Yeast extract is required for growth. The following substrates are utilized as carbon and energy sources in the presence of thiosulfate: betaine, formate, lactate, methanol and pyruvate. In the presence of sulfite, choline is also utilized, but formate is not. The following substrates do not support growth: $\mathrm{H}_{2} / \mathrm{CO}_{2}$, acetate, acetone, $\mathrm{D}(-)$-arabinose, benzoate, 2-butanol, butyrate, Casamino acids, choline chloride, ethanol, $\mathrm{D}(-)$-fructose, fumarate, $\mathrm{D}(+)$-galactose, $\mathrm{D}(+)$ glucose, glycerol, glycine, DL-malate, $\mathrm{D}(+)$-mannose, 1-pentanol, 2-propanol, propionate, $\mathrm{L}(+)$-rhamnose, succinate, sucrose and $\mathrm{D}(+)$-xylose. Elemental sulfur, sulfite, thiosulfate, nitrate and nitrite (at low concentrations) are utilized as electron acceptors. Sulfate and $\mathrm{Fe}$ (III) citrate are not reduced. The DNA G $+\mathrm{C}$ content is $41.6 \mathrm{~mol} \%$.

The type strain, sk.kt5 $5^{\mathrm{T}}\left(=\mathrm{DSM} 16504^{\mathrm{T}}=\mathrm{JCM} 12761^{\mathrm{T}}\right)$, was isolated from a biofilm growing in a high-pH district heating system in Denmark.

\section{Acknowledgements}

We thank Jacques Chevallier for providing transmission electron microscopy pictures of the novel strain and Tove Wiegers for technical assistance. This research was supported by the Danish Technical Research Council under the framework programme 'Activity and Diversity in Complex Microbial Systems'.

\section{References}

Abildgaard, L., Nielsen, M. B., Kjeldsen, K. U. \& Ingvorsen, K. (2006). Desulfovibrio alkalitolerans sp. nov., a novel alkalitolerant, sulphate-reducing bacterium isolated from district heating water. Int J Syst Evol Microbiol 56, 1019-1024.

Baker, B. J., Moser, D. P., MacGregor, B. J. \& 13 other authors (2003). Related assemblages of sulphate-reducing bacteria associated with ultradeep gold mines of South Africa and deep basalt aquifers of Washington State. Environ Microbiol 5, 267-277.

Balk, M., Weijma, J., Friedrich, M. W. \& Stams, A. J. M. (2003). Methanol utilization by a novel thermophilic homoacetogenic bacterium, Moorella mulderi sp. nov., isolated from a bioreactor. Arch Microbiol 179, 315-320.

Bower, C. E. \& Holm-Hansen, T. (1980). A salicylate-hypochlorite method for determining ammonia in sea water. Can J Fish Aquat Sci 37, 794-798.

Cline, J. D. (1969). Spectrophotometric determination of hydrogen sulfide in natural waters. Limnol Oceanogr 14, 454-458.

Elsgaard, L., Isaksen, M. F., Jørgensen, B. B., Alayse, A. M. \& Jannasch, H. W. (1994). Microbial sulfate reduction in deep-sea sediments at the Guaymas Basin hydrothermal vent area: influence of temperature and substrates. Geochim Cosmochim Acta 58, 3335-3343. 
Fontaine, F. E., Peterson, W. H., McCoy, E., Johnson, M. J. \& Ritter, G. J. (1942). A new type of glucose fermentation by Clostridium thermoaceticum. J Bacteriol 43, 701-706.

Hamilton, W. A. (1995). Biofilms and microbially influenced corrosion. In Microbial Biofilms, pp. 171-182. Edited by H. M. Lappin-Scott \& J. W. Costerton. Cambridge: Cambridge University Press.

Hungate, R. E. (1976). A roll tube method for cultivation of strict anaerobes. Methods Microbiol 3B, 117-132.

Imachi, H., Sekiguchi, Y., Kamagata, Y. \& 7 other authors (2006). Non-sulfate-reducing, syntrophic bacteria affiliated with Desulfotomaculum cluster I are widely distributed in methanogenic environments. Appl Environ Microbiol 72, 2080-2091.

Kjeldsen, K. U., Joulian, C. \& Ingvorsen, K. (2004). Oxygen tolerance of sulfate-reducing bacteria in activated sludge. Environ Sci Technol 38, 2038-2043.

Kjellerup, B. V., Olesen, B. H., Nielsen, J. L., Frølund, B., Ødum, S. \& Nielsen, P. H. (2003). Monitoring and characterisation of bacteria in corroding district heating systems using fluorescence in situ hybridisation and microautoradiography. Water Sci Technol 47 (5), $117-122$.

Kjellerup, B. V., Thomsen, T. R., Nielsen, J. L., Olesen, B. H., Frolund, B. \& Nielsen, P. H. (2005). Microbial diversity in biofilms from corroding heating systems. Biofouling 21, 19-29.

Lane, D. J. (1991). 16/23S rRNA sequencing. In Nucleic Acid Techniques in Bacterial Systematics, pp. 113-175. Edited by E. Stackebrandt \& M. Goodfellow. Chichester: Wiley.

Lee, W., Lewandowski, Z., Nielsen, P. H. \& Hamilton, W. A. (1995). Role of sulfate-reducing bacteria in corrosion of mild steel - a review. Biofouling 8, 165-193.

Little, B. J., Wagner, P. A., Characklis, W. G. \& Lee, W. (1990). Microbial corrosion. In Biofilms, pp. 635-670. Edited by W. G. Characklis \& K. C. Marshall. New York: Wiley.
Ljungdahl, L. G. (1986). The autotrophic pathway of acetate synthesis in acetogenic bacteria. Annu Rev Microbiol 40, 415-450.

Lovley, D. R. \& Phillips, E. J. P. (1986). Organic matter mineralization with reduction of ferric iron in anaerobic sediments. Appl Environ Microbiol 51, 683-689.

Ludwig, W., Strunk, O., Westram, R. \& 29 other authors (2004). ARB: a software environment for sequence data. Nucleic Acids Res 32, 1363-1371.

Marshall, K. C. (1992). Biofilms: an overview of bacterial adhesion, activity, and control at surfaces. ASM News 58, 202-207.

Mogensen, G. L., Kjeldsen, K. U. \& Ingvorsen, K. (2005). Desulfovibrio aerotolerans sp. nov., an oxygen tolerant sulfatereducing bacterium isolated from activated sludge. Anaerobe 11, 339-349.

Postgate, J. R. (1984). The Sulfate-reducing Bacteria, 2nd edn. Cambridge: Cambridge University Press.

Slobodkin, A., Reysenbach, A., Mayer, F. \& Wiegel, J. (1997). Isolation and characterization of the homoacetogenic thermophilic bacterium Moorella glycerini sp. nov. Int J Syst Bacteriol 47, 969-974.

Vandamme, P., Pot, B., Gillis, M., De Vos, P., Kersters, K. \& Swings, J. (1996). Polyphasic taxonomy, a consensus approach to bacterial systematics. Microbiol Rev 60, 407-438.

Widdel, F. \& Bak, F. (1992). Gram-negative mesophilic sulphatereducing bacteria. In The Prokaryotes, 2nd edn, pp. 3352-3378. Edited by A. Balows, H. G. Trüper, M. Dworkin, W. Harder \& K.-H. Schleifer. New York: Springer.

Wiegel, J., Braun, M. \& Gottschalk, G. (1981). Clostridium thermoautotrophicum sp. nov., a thermophile producing acetate from molecular hydrogen and carbon dioxide. Curr Microbiol 5, 255-260.

Zverlov, V., Klein, M., Lücker, S., Friedrich, M. W., Kellermann, J., Stahl, D. A., Loy, A. \& Wagner, M. (2005). Lateral gene transfer of dissimilatory (bi)sulfite reductase revisited. J Bacteriol 187, 2203-2208. 